\title{
Demographics-based differences in the relationship between perceived CSR and customer loyalty in the dairy products market
}

\author{
Ovidiu-Ioan MOISESCU
}

\author{
Babeș-Bolyai University, Cluj-Napoca, Romania
}

\begin{abstract}
The purpose of the current paper is to investigate the demographics-based differences in the relationship between customers' perceptions of corporate social responsibility (CSR) and their loyalty towards brands/companies in the dairy products market, considering the socio-cultural and economic particularities of one of the largest countries of Central-Eastern Europe. For this purpose, a survey was implemented among a sample of 1461 dairy products consumers from the urban area of Romania, investigating perceived CSR and customer loyalty by using 28, and, respectively, 6 Likert-type items. Results show that customers' loyalty towards dairy brands/companies is positively and significantly influenced by how customers perceive companies' responsibility towards their customers, in all investigated demographic segments. However, there are other facets of perceived CSR (community development, the environment, economic success, sponsorship, public authorities) in which case the relationship with customer loyalty is only significant in certain demographics-based market segments.
\end{abstract}

Keywords: corporate social responsibility, customer loyalty, dairy products, demographics.

Please cite the article as follows: Moisescu, O.I. (2015), "Demographics-based differences in the relationship between perceived CSR and customer loyalty in the dairy products market", Management \& Marketing. Challenges for the Knowledge Society, Vol. 10, No. 2, pp. 118-131, DOI: 10.1515/mmcks-2015-0010.

\section{Introduction}

As important literature topics especially during the last decades, corporate social responsibility (CSR) as well as customer loyalty have been proven to have the capacity to confer organizations several significant advantages. Many studies have suggested that CSR implementation accompanied by appropriate communication can enhance employee attraction, motivation and retention, improve customer satisfaction, or even fine tune the relationship between companies and their customers and other stakeholders (Kim and Park, 2011; Sen and Bhattacharya, 2001; Peloza and Shang, 2011). Research has shown that customer loyalty can also produce relevant business benefits such as business performance and long-term profitability (Reichheld, 2003; McMullan, 2005; Salegna and Goodwin, 2005).

Despite the fact that many researchers have focused their attention on the relationship between consumer behavior and perceived CSR, further and deeper investigation regarding how perceptions of CSR impact customer loyalty and especially how this relationship differs across various demographic categories is needed. The purpose of the current paper is to fill the previously described literature gap by investigating the demographics-based differences in the relationship between customers' perceptions of corporate social responsibility (CSR) and their loyalty towards brands/companies in the particular business sector of dairy products, and in Central and Eastern Europe.

Correspondence: Ovidiu Moisescu ovidiu.moisescu @econ.ubbcluj.ro 
Even though focusing on a specific industry within a particular national market might seem a narrow approach, both the analyzed sector and the investigated region are of high importance for the topic of CSR.

Considering the specific socio-cultural and economic context of Central and Eastern European countries, researchers agree that CSR empirical testing has not been rigorously done yet (Popa and Salanță, 2014), the current regional knowledge regarding the relationship between perceived CSR and customer loyalty being scarce. CSR communications and practices are rather new to Central and Eastern European consumers who were still living in soviet and communist dominated societies in the early 1990s. Moreover, the region as a group of developing countries has certain particularities which make it very different from other regions comprising developed countries, and in which consumers' perceptions of CSR and the impact of CSR on consumer behavior have been extensively investigated. As Malhotra et al. (2005) show, consumers' understanding and reactions to certain established business policies can significantly differ between developed and developing countries, and therefore research findings regarding a certain topic in developed countries should not be generalized to developing ones, but rather revisited by conducting new research.

However, many companies continue to plan and to assess their CSR in developing countries within a global policy, expecting local consumers to react to CSR in the same way those from developed countries do. Furthermore, many businesses develop and implement CSR actions and communications without targeting particular demographic-based market segments, or, if they do so, this is not done based on accurate scientific knowledge regarding the differences between these segments in what concerns their reaction to CSR.

In what concerns the investigated industry, it must be stated that the dairy products sector is extremely relevant from a CSR perspective, having several specific externalities related to the environment, local labor, local economic development, food safety and other CSR related issues. The dairy industry represents an important part of human life and a relevant factor of population health, while also being an important element of the national economy in many countries (Maloni and Brown, 2006; Murdoch et al., 2000). Moreover, the dairy sector is labor intensive, and therefore improving working condition for local employees and paying fair prices to local suppliers are of high relevance (Maloni and Brown, 2006). All these aspects suggest that CSR in the dairy industry should receive more attention from both industry stakeholders and researchers.

Considering the relevance of both the investigated industry and the analyzed region for the topic of CSR, and taking into account the fact that demographics have been generally ignored in previous studies regarding the connection between perceived CSR and customer loyalty, this paper provides a relevant contribution to the existing literature, while also having practical implications for managing CSR communications among various demographics-based market segments in the Central and Eastern European dairy industry.

\section{Literature review}

Despite a rather ambiguous state of affairs in what concerns the definition of the concept of CSR (Dahlsrud, 2008), the literature outlines at least three basic and widely supported approaches regarding the CSR systematization: Carroll's (1979) approach, according to which CSR is seen as comprising the economic, legal, ethical and discretionary (philanthropic) responsibilities of organizations, the sustainable 
MMCKS development approach, according to which CSR is regarded as comprising economic, environmental, and social responsibilities of companies, and, last but not least, the stakeholder-based approach (Freeman et al., 2010), in which case companies' social responsibilities are classified into responsibilities towards shareholders, customers, employees, the environment, society, and other specific stakeholders.

Customer loyalty is a much more established and less ambiguous concept, several but relatively similar approaches being outlined in the literature up to date. However, there are certain differences among these, mostly concerned with the exclusiveness of loyalty and, respectively, its behavioral or attitudinal nature. Thus, the American Marketing Association defines customer loyalty as the situation in which a consumer generally buys the same manufacturer-originated product repeatedly over time rather than buying from multiple suppliers within the category. In this definition, loyalty is seen as exclusive and behavioral. The same situation can be outlined in Aaker's (1991) definition which implies that customer loyalty is a reflection of how likely a consumer is to switch to another supplier, especially when that supplier makes a change in its marketing programs. Nevertheless, the most important contribution to the definition of customer loyalty comes from Jacoby and Chestnut (1978) who regard it as a function of psychological processes materialized in the biased behavioral response expressed over time by consumers with respect to one or more alternative brands out of a set of brands. Customer loyalty is thus seen as non-exclusive in nature, with a dualistic character, being both behavioral and attitudinal. Jacoby and Chestnut (1978) basically state that repeat buying behavior must be accompanied by psychological commitment in order for customer loyalty to be genuine.

Furthermore, the most relevant and up-to-date findings regarding the impact of perceived CSR on customer loyalty in the dairy products market are explored, taking into account the literature comprised in Web of Science and Scopus, the most widespread and frequently used literature databases (Norris and Oppenheim, 2007). Thus, a couple of relevant papers can be identified as being very closely related to the theme of current paper. Du et al. (2007), after a survey conducted among American consumers of yogurt products, came to the conclusion that positive consumers' CSR perceptions are associated with greater purchase likelihood, and also with longer-term loyalty and advocacy behaviors. Moreover, the authors suggest that CSR implementation and communication is not as effective in generating short term sales, as in deepening customer relationships over time, thus creating company/brand advocates. More recently, Perrini et al. (2010) conducted a consumer survey among Italian purchasers of organic yogurt products and concluded that consumers' perceptions of CSR in what regards companies' responsibilities towards customers and the environment have a positive and significant influence on brand trust, while brand trust further positively influences both brand loyalty and consumers' willingness to pay premium prices for products sold within the investigated market.

Other relevant studies concerning the relationship between perceived CSR and customer loyalty in related or similar industries are also further analyzed. Thus, Pivato et al. (2008), after measuring CSR perceptions among Italian purchasers of organic food products (considering companies' responsibilities towards customers, employees and the environment) suggested that perceived CSR, as a composite variable, has an indirect positive effect on customer loyalty, brand trust being a mediating variable. Research conducted by Pirsch et al. (2007) within the American food products market revealed that not all categories of CSR programs have a similar effect on loyalty, institutionalized CSR programs being more effective at increasing customer loyalty, while promotional 
CSR programs more efficient in generating purchase intent. Singh et al. (2012), after conducting a research among Spanish customers of fast moving consumer goods (including food products) companies, suggested that there was a positive relationship between customers' perceptions of brand ethicality and, respectively, brand trust and emotional attachment, these being also positively correlated with customer loyalty. Last but not least, Anselmsson et al. (2014), after investigating a sample of Swedish food products buyers, came to the conclusion that consumers' willingness to pay price premiums (as a partial reflection of customer loyalty) was significantly impacted by quality, social image, uniqueness, home country origin, awareness, as well as perceived CSR.

\section{Research methodology}

The purpose of the current paper is to investigate the demographics-based differences in the relationship between customers' perceptions of CSR and their loyalty towards dairy brands/companies from Central and Eastern Europe. The dairy industry was selected not only because of its relevance to the issue of CSR, but also due to the fact that the CSR actions and policies of the main competitors from the industry have a high visibility in the local mainstream media (one of the main competitors being, for example, among the nominees of the European CSR Award in 2013). Thus, perceptions of CSR regarding the sectors' main competitors were expected to be crystalized in the minds of many consumers and, therefore, their assessment to be relevant. Moreover, the industry was also targeted because it refers to products with a large penetration among the local urban population, and, therefore, the potential subjects of the study (customers of dairy companies) could be easily found and targeted.

In order to accomplish the current paper's goal, a consumer survey was implemented among a sample of 1461 urban Romanian dairy products consumers, between January-March 2015. The data was collected using a paper and pencil (selfadministered) questionnaire including 28 items for measuring CSR perceptions, and, respectively, 6 items for evaluating customer loyalty. The final item pool used for assessing perceived CSR and customer loyalty (Table 1) resulted from a preliminary item pool created on the basis of an extended literature review, which was further refined with the support of several marketing specialists (especially marketing professors and $\mathrm{PhD}$ students) by removing ambiguous, redundant or customer imperceptible items.

Table 1. Final item pool for assessing perceived CSR and customer loyalty

\begin{tabular}{lll}
\hline Items & & Sources $^{*}$ \\
\hline CSR1 & Strives to maximize profits and improve economic and financial performance & {$[1,2,3,4]$} \\
\hline CSR2 & Pursues its success in the long term, not only in the short term & {$[1,2,3,4]$} \\
\hline CSR3 & Strives to offer its customers products/services of reasonable quality & {$[2]$} \\
\hline CSR4 & Is concerned with its customers' satisfaction & {$[3,5]$} \\
\hline CSR5 & $\begin{array}{l}\text { Provides customers with honest \& complete information about } \\
\text { products/services }\end{array}$ & {$[2,3,5,6]$} \\
\hline CSR6 & Charges fair and reasonable prices for its products/services & {$[2,6]$} \\
\hline CSR7 & $\begin{array}{l}\text { Provides safe products/services, not-threatening to physical/mental health of } \\
\text { buyers }\end{array}$ & {$[2,6]$} \\
\hline CSR8 & Works diligently to handle and solve its customers' complaints & {$[2,3]$} \\
\hline CSR9 & Pays its employees fairly and in a reasonable manner & {$[2,3,6]$} \\
\hline CSR10 & Offers its employees decent working conditions & {$[2,3,6]$} \\
\hline CSR11 & Does everything possible to prevent and avoid discrimination of employees & {$[2,3,6]$} \\
\hline CSR12 & Respects the rights of its employees & {$[1,2,5]$}
\end{tabular}

Vol.10, No. 2, Spring, pp. 118-131, ISSN 1842-0206 | Management \& Marketing. Challenges for the Knowledge Society 
CSR14 Provides professional development and promotion opportunities to its $[2,3,5]$ employees

\begin{tabular}{lll}
\hline CSR15 & $\begin{array}{l}\text { Does everything possible to reduce its negative effects on the natural } \\
\text { environment }\end{array}$ & {$[2,3,5,6]$} \\
\hline CSR16 & $\begin{array}{l}\text { Strives to minimize the consumption of resources that affect the natural } \\
\text { environment }\end{array}$ & {$[2]$} \\
\hline CSR17 & Works diligently to use environmentally friendly materials & {$[2,3,5,6]$} \\
\hline CSR18 & Is concerned with the proper management of waste and recycling activities & {$[2,6]$} \\
\hline CSR19 & Contributes to the economic growth and development of the region & {$[2]$} \\
\hline CSR20 & Contributes to the long-term welfare and life quality of people in the region & {$[1,3,4,5]$} \\
\hline CSR21 & Creates and sustains jobs in the region & {$[2]$} \\
\hline CSR22 & Contributes to the development of other companies in the region & {$[2]$} \\
\hline CSR23 & Respects the values, customs and culture of the region & {$[2]$} \\
\hline CSR24 & Supports charitable and social projects addressed to the disadvantaged & {$[1,2,3,4,5]$} \\
\hline CSR25 & Supports cultural and social events (music, sports, etc.) & {$[3,4]$} \\
\hline CSR26 & Fully complies with the legislation in conducting its activities & {$[1,4,5,6]$} \\
\hline CSR27 & Always pays state taxes in a fairly and honestly manner & {$[5,6]$} \\
\hline CSR28 & $\begin{array}{l}\text { Does everything possible to prevent and avoid corruption in its relation with the } \\
\text { state }\end{array}$ & {$[6]$} \\
\hline LOY1 & I consider myself a loyal customer of this company & {$[9,10]$} \\
\hline LOY2 & This company is my first choice, compared to others in the sector & {$[8,11]$} \\
\hline LOY3 & I will continue to be a customer of this company & {$[7,8]$} \\
\hline LOY4 & In the future I plan to purchase more from this company & {$[11]$} \\
\hline LOY5 & I would recommend this company to my friends and acquaintances & {$[7,8,11]$} \\
\hline LOY6 & I wouldn't give up being a customer even if a competitor came up with a better & {$[11]$} \\
& offer
\end{tabular}

Source: Adapted from [1] Maignan, 2001; [2] Öberseder et al., 2014; [3] Pérez and Bosque, 2013; [4] Salmones et al., 2005; [5] Turker, 2009; [6] Wagner et al., 2008; [7] Cronin et al., 2000; [8] Martínez and Bosque, 2013; [9] Rosenbaum, 2006; [10] Sloot et al., 2005; [11] Zeithaml et al., 1996.

Each participant was asked to mention a specific dairy product brand they had recently bought, and afterwards to refer to the company that produces/sells that brand, rating each of the 28 CSR items ("I believe that this company ...") and 6 loyalty items on a Likert scale ranging from 1="strongly disagree" to 7="strongly agree", with a middle/neutral point. The sampling procedure was non-probabilistic and mixed. Thus, both snowball sampling and quota sampling (by age and gender) were employed so that a sample with a diversified demographic composition could be obtained (Table 2). Regarding the demographic structure of the sample, it is worth mentioning that subjects were asked to assess their income as compared to the average income in their region instead of disclosing their actual income, for confidentiality reasons and so that missing values could be avoided.

\begin{tabular}{lr}
\multicolumn{2}{c}{ Table 2. Sample demographics } \\
Gender & 719 \\
\hline Men & 742 \\
Women & 1461 \\
Total & \\
Age & 556 \\
$18-29$ years & 518 \\
30 - 44 years & 387 \\
45 - 56 years & 1461 \\
Total & 225 \\
Family income (as compared to the average income) \\
Lower & 878
\end{tabular}




\begin{tabular}{lr}
$\begin{array}{l}\text { Higher } \\
\text { Total }\end{array}$ & 358 \\
Highest level of education & 1461 \\
\hline High-school or lower & 739 \\
BA & 443 \\
MA or higher & 279 \\
Total & 1461 \\
Type of residence & \\
\hline Cities with less up to 50,000 inhabitants & 501 \\
Cities with 50,001 to 200,000 inhabitants & 461 \\
Cities with more than 200,000 inhabitants & 499 \\
Total & 1461
\end{tabular}

Source: Author's own research.

\section{Research results}

An exploratory factor analysis was conducted in order to reduce the large number of observable variables (items) to a lower number of reflective latent variables (components). The factor analysis revealed that the six loyalty indicators can be adequately grouped into one single latent variable, while the 28 perceived CSR items into seven components (Table 3 ).

Table 3. Latent variables

\begin{tabular}{llc}
\hline Latent reflective variables & Items & Variance explained \\
\hline Economic success & CSR 1-2 & $6.356 \%$ \\
\hline Customers & CSR 3-8 & $8.945 \%$ \\
\hline Employees & CSR 9-14 & $13.967 \%$ \\
\hline Environment & CSR 15-18 & $8.999 \%$ \\
\hline Community development & CSR 19-23 & $9.941 \%$ \\
\hline Sponsorship & CSR 24-25 & $5.062 \%$ \\
\hline Public authorities & CSR 26-28 & $6.370 \%$ \\
\hline Customer loyalty & LOY 1-6 & $11.803 \%$ \\
\hline
\end{tabular}

Source: Author's own research. Notes: Exploratory factor analysis; Varimax rotation; $\mathrm{KMO}=.930>.9$; Bartlett's test of sphericity: Chi-square $=31259.616 ; \mathrm{df}=561 ; \mathrm{p}<.001$; Total variance explained: $71.443 \%$.

After computing average scores for each latent variable, a multiple linear regression model was proposed (Figure 1) in which the latent variables regarding CSR perceptions were included as predictors (independent variables), while the latent variable corresponding to customer loyalty was inserted as dependent variable.

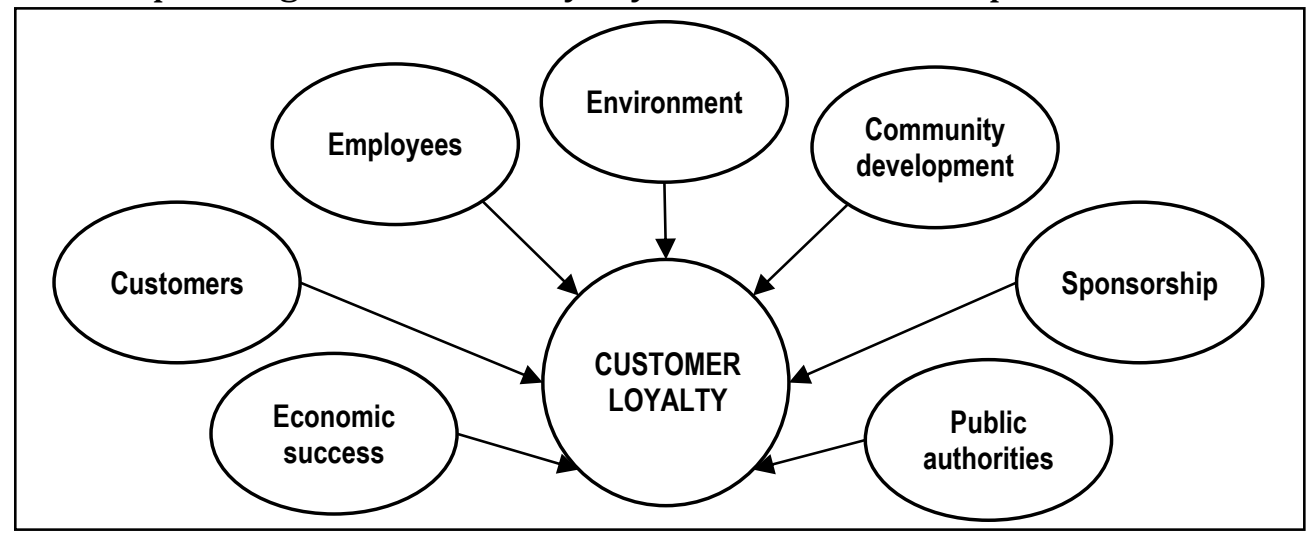

Figure 1: Proposed model

Source: Author's own research. 
MMCKS Furthermore, considering the current paper's purpose, the proposed model was successively and comparatively tested within different customer categories, based on demographics such as gender, age, relative income, education, and, respectively, type of residence. Therefore, the following research hypotheses were issued:

The impact of perceived CSR on customer loyalty differs among:

H1: ... gender based consumer categories.

H2: ... age based consumer categories.

H3: ... income level based consumer categories.

H4: ... education level based consumer categories.

H5: ... residence type based consumer categories.

Table 4. Gender-based multiple linear regression standardized coefficients

\begin{tabular}{lrrrrrr}
\hline & \multicolumn{2}{c}{ Men $\left(\mathrm{R}^{2}=.355 ;\right.$} & \multicolumn{3}{c}{ Women $\left(\mathrm{R}^{2}=.350 ;\right.$} \\
& \multicolumn{2}{c}{$\mathrm{F}(7,711)=55.974 ;$} & \multicolumn{3}{c}{$\mathrm{F}(7,734)=56.471 ;$} \\
& $\mathrm{p}<.001)$ & & $\mathrm{p}<.001)$ & $\mathrm{p}$ \\
& Beta & $\mathrm{t}$ & $\mathrm{p}$ & Beta & $\mathrm{t}$ & $\mathrm{p}$ \\
\hline Economic success & -.085 & -2.593 & .010 & -.026 & -.747 & .455 \\
\hline Customers & .402 & 10.516 & .000 & .441 & 11.360 & .000 \\
\hline Employees & .010 & .255 & .799 & .024 & .597 & .551 \\
\hline Environment & .069 & 1.782 & .075 & .062 & 1.600 & .110 \\
\hline Community development & .214 & 5.947 & .000 & .075 & 1.977 & .048 \\
\hline Sponsorship & -.008 & -.217 & .828 & .076 & 2.057 & .040 \\
\hline Public authorities & .102 & 2.496 & .013 & .082 & 2.056 & .040 \\
\hline
\end{tabular}

Source: Author's own research.

The results in Table 4 suggest the fact that there is a similar positive impact of perceived CSR on customer loyalty in both gender-based categories, the variance in customer loyalty accounted for by customers' perceptions of CSR being approximately the same in both cases (35.5\% versus $35.0 \%$ ).

However, even though in both gender categories the most influential CSR perception refers to how consumers perceive companies' responsibility towards their customers (Beta=.402/.441), while both categories are similarly sensitive to how companies' fulfill their responsibilities towards public authorities (Beta=.102/.082), there are gender differences in what concerns how customer loyalty is impacted by companies' perceived responsibilities towards economic success, community development, and sponsorship. Thus, men's loyalty is negatively influenced by the companies' orientation towards their own economic success (Beta=-.085; $p<.05$ ), while this relationship is not significant in the case of women ( $p>>.05)$.

Moreover, men's loyalty is more influenced by the companies' responsibilities towards community development as compared to the case of women (Beta $=.214$ versus Beta=.075). Last but not least, women's loyalty is positively influenced by their perceptions of the companies' responsibility towards sponsorship (Beta=.076; $<<.05$ ), while the impact of this CSR dimension on men's loyalty is not significant ( $p>>.05)$. As it can be seen, CSR perceptions regarding employees or the environment do not significantly influence customer loyalty in any of the analyzed demographic categories ( $p>>.05$ ). However, considering the above described findings, research hypothesis $H 1$ is accepted. 
Table 5. Age-based multiple linear regression standardized coefficients

\begin{tabular}{|c|c|c|c|c|c|c|c|c|c|}
\hline & \multicolumn{3}{|c|}{$\begin{array}{c}\mathbf{1 8 - 2 9}\left(\mathrm{R}^{2}=.347\right. \\
\mathrm{F}(7,548)=41.674 \\
\mathrm{p}<.001)\end{array}$} & \multicolumn{3}{|c|}{$\begin{array}{c}\text { 30-44 }\left(\mathrm{R}^{2}=.398\right. \\
\mathrm{F}(7,510)=48.153 \\
\mathrm{p}<.001)\end{array}$} & \multicolumn{3}{|c|}{$\begin{array}{c}\text { 45-56 }\left(\mathrm{R}^{2}=.316\right. \\
\mathrm{F}(7,379)=25.065 \\
\mathrm{p}<.001)\end{array}$} \\
\hline & Beta & $\mathrm{t}$ & $\mathrm{p}$ & Beta & $\mathrm{t}$ & $\mathrm{p}$ & Beta & $\mathrm{t}$ & $\mathrm{p}$ \\
\hline Economic success & -.029 & -.737 & .461 & -.048 & -1.232 & .218 & -.122 & -2.650 & .008 \\
\hline Customers & .404 & 9.108 & .000 & .425 & 9.309 & .000 & .463 & 8.830 & .000 \\
\hline Employees & -.015 & -.333 & .739 & -.011 & -.243 & .808 & .099 & 1.723 & .086 \\
\hline Environment & .050 & 1.155 & .249 & .110 & 2.387 & .017 & .034 & .600 & .549 \\
\hline Community development & .157 & 3.632 & .000 & .164 & 3.910 & .000 & .098 & 1.896 & .059 \\
\hline Sponsorship & .019 & .442 & .659 & .041 & .979 & .328 & .043 & .756 & .450 \\
\hline Public authorities & .147 & 3.237 & .001 & .088 & 1.872 & .062 & -.003 & -.043 & .966 \\
\hline
\end{tabular}

As it can be seen in Table 5 the variance in customer loyalty accounted for by customers' perceptions of CSR is lower in the case of consumers of 45-56 years of age (31.46\%), as compared to younger ones (34.7\% and 39.8\%). Thus, the results suggest that the positive impact of perceived CSR, as a whole, on customer loyalty is lower in the case of consumers between 45-56 years of age (as compared to other age categories). However, there are certain dissimilarities in what concerns this impact considering CSR dimensions individually. Thus, only older (45-56 years of age) consumers' loyalty is significantly impacted by their perceptions of companies' responsibilities towards their own economic success, this impact being negative (Beta=-.122; $\mathrm{p}=.008$ ). On the other hand, these older consumers are not loyalty-sensitive to other CSR aspects such as the environment, community development or public authorities, which have certain significant influences on loyalty in other age categories. Thus, the youngest consumers are the only ones that are loyalty-sensitive to how they perceive companies' responsibilities towards public authorities (Beta=.147; $\mathrm{p}=.001$ ), while middle-aged consumers are the only ones whose loyalty is influenced by how they perceive companies' responsibilities towards the environment (Beta=.110; $\mathrm{p}<.05$ ). Therefore, considering the previously described findings, research hypothesis $H 2$ is accepted. Overall, the results indicate the fact that in all demographic categories the most loyaltyinfluential CSR perception refers to how customers perceive companies' responsibility towards their customers (Beta=.404/.425/.463), while perceptions regarding companies' responsibilities towards employees and sponsorship have no significant impact on customer loyalty.

The results suggest that in order to enhance customer loyalty in the dairy industry, CSR actions and communications regarding certain domains should be adapted to age-based market segments. Thus, corporate responsibility towards public authorities should be emphasized especially among young consumers, while companies' responsibility towards the environment should be mainly conveyed to the middle-aged. However, other responsibilities such as those regarding customers and community development need to be communicated to all age-segments, as their perceptions significantly impact loyalty for most consumers in the industry, regardless of their age. 
Table 6. Income-based multiple linear regression standardized coefficients

\begin{tabular}{|c|c|c|c|c|c|c|c|c|c|}
\hline & \multicolumn{3}{|c|}{$\begin{array}{c}\text { Lower }\left(\mathrm{R}^{2}=.405\right. \\
\mathrm{F}(7,217)=21.148 \\
\mathrm{p}<.001)\end{array}$} & \multicolumn{3}{|c|}{$\begin{array}{c}\text { Similar }\left(R^{2}=.347 ;\right. \\
F(7,870)=66.022 ; \\
p<.001)\end{array}$} & \multicolumn{3}{|c|}{$\begin{array}{c}\text { Higher }\left(R^{2}=.355\right. \\
F(7,350)=27.483 \\
p<.001)\end{array}$} \\
\hline & Beta & $\mathrm{t}$ & $\mathrm{p}$ & Beta & $\mathrm{t}$ & $\mathrm{p}$ & Beta & $\mathrm{t}$ & $\mathrm{p}$ \\
\hline Economic success & -.013 & -.207 & .836 & -.059 & -1.916 & .056 & -.062 & -1.312 & .190 \\
\hline Customers & .373 & 5.159 & .000 & .451 & 12.923 & .000 & .427 & 7.842 & .000 \\
\hline Employees & -.074 & -.899 & .370 & .046 & 1.334 & .183 & -.049 & -.853 & .394 \\
\hline Environment & .180 & 2.512 & .013 & .044 & 1.250 & .212 & .039 & .704 & .482 \\
\hline Community development & .031 & .453 & .651 & .164 & 4.794 & .000 & .180 & 3.617 & .000 \\
\hline Sponsorship & .131 & 1.912 & .057 & .016 & .465 & .642 & .013 & .251 & .802 \\
\hline Public authorities & .190 & 2.482 & .014 & .040 & 1.100 & .271 & .162 & 2.744 & .006 \\
\hline
\end{tabular}

Source: Author's own research.

Results in Table 6 show that the variance in customer loyalty accounted for by customers' perceptions of CSR is the highest in the case of customers with lower than average income (40.5\%), as compared to customers with an average or higher than average income (34.7\% and 35.5\%). Results indicate that in all income-based consumer categories the most influential CSR perception refers to how consumers perceive companies' responsibility towards their customers (Beta=.373/.451/.427), while in none of them perceptions regarding companies' responsibilities towards employees or sponsorship have any significant impact on customer loyalty ( $p>.05$, or even $p>>.05$ ). However, considering individually other CSR aspects, certain dissimilarities among income categories can be outlined. Thus, perceptions regarding the companies' responsibility towards the environment positively influence loyalty only in the case of customers with lower than average income (Beta=.180; $\mathrm{p}<.05$ ), while, on the other hand, this income-based consumer category is the only one which is not loyaltysensitive to perceived CSR towards community development ( $p>>.05)$. Moreover, consumers with an average income are the only ones who do not seem to be loyaltysensitive when it comes to perceived CSR towards public authorities ( $p>>.05$ ). The previously described findings imply the acceptance of research hypothesis $H 3$.

The results indicate that in order to obtain a higher loyalty from customers in the dairy industry, certain CSR actions and communications should be tailored according to specific expected reactions of each income-based market segment. Thus, corporate responsibility towards the environment should be emphasized especially among consumers with a lower than average income, while responsibilities towards community development should be mainly conveyed to consumers with an average or higher than average income level. Of course, there are also corporate responsibilities in which case consumers' reaction in terms of loyalty is positively influenced regardless of their income level (e.g. responsibility towards customers).

Table 7. Education-based multiple linear regression standardized coefficients

\begin{tabular}{lrrrrrrrrr}
\hline & \multicolumn{2}{c}{ High-school $\left(\mathrm{R}^{2}=.288 ;\right.$} & \multicolumn{2}{c}{ BA $\left(\mathrm{R}^{2}=.380 ;\right.$} & \multicolumn{3}{c}{ MA, PhD $\left(\mathrm{R}^{2}=.472 ;\right.$} \\
& \multicolumn{2}{c}{$\mathrm{F}(7,731)=42.317 ;$} & \multicolumn{2}{c}{$\mathrm{F}(7,435)=38.116 ;$} & \multicolumn{2}{c}{$\mathrm{F}(7,271)=34.612 ;$} \\
& $\mathrm{p}<.001)$ & & \multicolumn{2}{c}{$\mathrm{p}<.001)$} & & $\mathrm{p}<.001)$ & $\mathrm{p}$ \\
& $\mathrm{Beta}$ & $\mathrm{t}$ & $\mathrm{p}$ & Beta & $\mathrm{t}$ & $\mathrm{p}$ & Beta & $\mathrm{t}$ & $\mathrm{p}$ \\
\hline Economic success & -.026 & -.752 & .453 & -.094 & -2.209 & .028 & -.066 & -1.325 & .186 \\
\hline Customers & .344 & 8.578 & .000 & .460 & 9.634 & .000 & .560 & 9.594 & .000 \\
\hline Employees & .002 & .045 & .964 & .037 & .758 & .449 & -.018 & -.296 & .767 \\
\hline Environment & .047 & 1.173 & .241 & .079 & 1.637 & .102 & .086 & 1.493 & .137 \\
\hline Community development & .172 & 4.426 & .000 & .130 & 2.804 & .005 & .147 & 2.694 & .008 \\
\hline Sponsorship & .020 & .509 & .611 & .053 & 1.110 & .267 & .048 & .890 & .374 \\
\hline Public authorities & .126 & 3.026 & .003 & .061 & 1.201 & .230 & .023 & .367 & .714 \\
\hline
\end{tabular}

Source: Author's own research. 
As it can be seen from Table 7, the variance in customer loyalty accounted for by customers' perceptions of CSR increases significantly as the education level gets higher $(28.8 \% / 38.0 \% / 47.2 \%)$. Therefore, it can be stated that the more educated consumers are, the more powerful the impact of perceived CSR on their loyalty is in the specific market of dairy products. Results also reveal the fact that in all education categories the most influential CSR perception refers to how consumers perceive companies' responsibility towards their customers (Beta=.344/.460/.560), followed by how customers perceive CSR responsibilities towards community development (Beta=.172/.130/.147). Moreover, no matter the education level, customers' perceptions regarding companies' responsibilities towards employees, the environment, or sponsorship have no significant influence on their loyalty ( $p>>.05$ ). However, there are two education-based differences in what concerns the perceived CSR towards economic success and public authorities. Thus, only consumers with BA studies are loyalty-sensitive when it comes to companies' responsibility towards their own economic success, the impact being negative (Beta $=-.094 ; \mathrm{p}<.05$ ), and only less educated consumers' loyalty is impacted (positively) by how they perceive companies' responsibility towards public authorities (Beta=.126; $\mathrm{p}=.003$ ). Considering the above described findings, research hypothesis $H 4$ is accepted.

The findings outline the fact that enhancing customer loyalty in the dairy industry using CSR actions and communications should be done in a particular manner for certain education-based market segments when it comes to corporate responsibilities towards economic success or public authorities. Thus, emphasizing leadership based on profits and financial aspects should be avoided among consumers with BA studies, while responsibilities regarding paying taxes, avoiding corruption or complying with legal issues should be especially emphasized among less educated consumers.

Table 8. Residence-based multiple linear regression standardized coefficients

\begin{tabular}{|c|c|c|c|c|c|c|c|c|c|}
\hline & \multirow{2}{*}{\multicolumn{6}{|c|}{$\begin{array}{c}\mathbf{5 0 - 2 0 0} \text { thsd } \\
\left(\mathrm{R}^{2}=.341\right. \\
\mathrm{F}(7,453)=33.434 \\
\mathrm{p}<.001)\end{array}$}} & \multirow{2}{*}{\multicolumn{3}{|c|}{$\begin{array}{c}>200 \text { thsd }\left(\mathrm{R}^{2}=.355\right. \\
\mathrm{F}(7,491)=38.641 ; \\
\mathrm{p}<.001)\end{array}$}} \\
\hline & & & & & & & & & \\
\hline & Beta & $\mathrm{t}$ & $\mathrm{p}$ & Beta & $\mathrm{t}$ & $\mathrm{p}$ & Beta & $\mathrm{t}$ & $\mathrm{p}$ \\
\hline Economic success & -.036 & -.922 & .357 & -.078 & -1.820 & .069 & -.061 & -1.492 & .136 \\
\hline Customers & .487 & $\begin{array}{r}10.62 \\
7\end{array}$ & .000 & .345 & 7.085 & .000 & .435 & 9.349 & .000 \\
\hline Employees & .005 & .107 & .915 & .043 & .868 & .386 & -.007 & -.140 & .889 \\
\hline Environment & .059 & 1.263 & .207 & .105 & 2.048 & .041 & .031 & .679 & .497 \\
\hline Community development & .081 & 1.798 & .073 & .243 & 5.337 & .000 & .133 & 2.935 & .003 \\
\hline Sponsorship & .038 & .831 & .406 & .062 & 1.295 & .196 & .003 & .059 & .953 \\
\hline Public authorities & .084 & 1.738 & .083 & .008 & .149 & .882 & -.061 & -1.492 & .136 \\
\hline
\end{tabular}

Finally, results in Table 8 show that customer loyalty, in all residence-based consumer segments, is positively and significantly impacted by how customers perceive companies' responsibility towards their customers (Beta=.487/.345/.435), while perceptions regarding CSR aspects related to economic success, employees, sponsorship, or public authorities do not significantly impact any segment's loyalty level ( $p>.05$, or even $p>>.05$ ). As a whole, the variance in customer loyalty accounted for by customers' perceptions of CSR is much larger in the case of consumers from smaller cities (61\%), as compared to those coming from medium or large cities $(34.1 \% / 35.5 \%)$. 
MMCKS However, only CSR towards customers represents a significant influence on customer loyalty in the case of customers residing in small cities, all other CSR dimensions being insignificant predictors in the model. On the other hand, if residents from medium and large cities are taken into consideration it can be seen that their loyalty towards dairy brands/companies is significantly and positively influenced by companies' responsibilities towards the environment (for medium cities residents; Beta=.105; $\mathrm{p}<.05$ ), and towards community development (both in the case of medium and large cities' residents), with a stronger impact in the case of residents from medium sized cities (Beta $=.243$ and $p<.001$ versus Beta $=.133$ and $p=.003$ ). Overall, due to the above described findings, research hypothesis $H 5$ is accepted.

The above described results suggest that in order to improve customers' loyalty in the dairy industry, CSR actions and communications regarding the environment and community development should be adapted to residence-based market segments. Thus, such responsibilities should be mostly disseminated among residents from medium and large cities, while emphasizing them to consumers from small cities would be inefficient if customer loyalty is the main expected outcome.

\section{Conclusions}

The current research manages to fill an important regional knowledge gap by analyzing the demographics-based differences in the relationship between customers' perceptions of CSR and their loyalty towards dairy products brands/companies from one of the largest Central and Eastern European countries. Results show that loyalty towards dairy products brands/companies is positively and significantly influenced by how customers perceive companies' responsibility towards their customers, this being the most influential CSR dimension in all demographics-based segments. Moreover, perceptions regarding companies' responsibilities towards community development, as well as public authorities have a positive and significant impact on customer loyalty in many of the investigated consumer segments. However, perceived CSR in what concerns employees does not affect customer loyalty in any analyzed segments, while perceptions of CSR regarding economic success, the environment, or sponsorship are only relevant in a few demographics-based categories.

The research reveals several significant demographics-based dissimilarities in what concerns the nature and intensity of the relationship between perceived CSR and customer loyalty. Thus, men's loyalty is negatively influenced by companies' orientation towards their own economic success, while this relationship is not significant in the case of women. On the other hand, women's loyalty is positively influenced by their perceptions of companies' responsibilities towards sponsorship, while the impact of this perception on men's loyalty is not significant. Also, the positive impact of perceived CSR, as a whole, on customer loyalty is lower in the case of older consumers. Moreover, perceptions regarding companies' responsibility towards the environment positively influence loyalty only in the case of customers with lower than average income, while, on the other hand, this income-based consumer category is the only one which is not loyalty-sensitive to perceived CSR towards community development. Another important finding reflects the fact that the more educated consumers are, the more powerful the impact of perceived CSR on their loyalty is, although companies' responsibility towards public authorities only impacts customer loyalty in the case of those less educated. Last but not least, in the case of consumers residing in smaller cities customer loyalty is significantly influenced only by one type of CSR perceptions, more specifically by how they perceive companies' responsibility towards their customers.

Vol.10, No. 2, Spring, pp. 118-131, ISSN 1842-0206 | Management \& Marketing. Challenges for the Knowledge Society 
The findings presented in this paper have practical implications in what concerns the adequate focus and marketing communication of CSR in the Central and Eastern European dairy products market. Thus, companies that operate in the industry and the specific regional context and wish to enhance their customers' loyalty should be focused on communicating their responsibility towards customers (concerned with customers' satisfaction and solving customers' complaints, providing high quality and safe products, providing honest and complete information about products, and charging fair and reasonable prices) in all demographics-based market segments. However, depending on the market segment they are targeting, perceptions of other responsibilities should be communicated with selective emphasis.

One of the main limitations of this research refers to the fact that possible mediating factors of the relationship between customers' perceptions of CSR and customer loyalty were not taken into account. Thus, the investigation could be extended by integrating several mediating variables (e.g. customer satisfaction, customer trust, company-consumer identification, price-quality competitive positioning, perceived switching costs etc.) into a structural equations model along with perceptions of CSR as exogenous variables, and, respectively, customer loyalty as endogenous variable.

Another limitation of the current research comes from the specifics of the investigated industry (dairy products) such as its particular implications in what concerns consumers' health and animal welfare. Products' safety and consumers' health represent important topics of concern in nowadays globalized food industry (Murdoch et al., 2000). Moreover, the dairy industry has become an important part of human life, the health of people all over the world significantly relating to this sector (Maloni and Brown, 2006). In what concerns animal welfare, as the dairy industry involves livestock operations, and due to the rising consumer awareness of the issues related to this aspect, the sector has become a particularly relevant ground for CSR from the animal welfare perspective (Lusk and Norwood, 2012). However, even though the current research takes into account product safety issues when measuring perceived CSR, certain aspects regarding consumers' health and animal welfare were not specifically included in the investigation. Therefore, as another future research opportunity, the study could be broadened by assessing consumers' perceptions regarding these aspects, and investigating the relationship between these perceptions and customer loyalty.

\section{Acknowledgements}

This work was supported from the European Social Fund through Sectorial Operational Programme Human Resources Development 2007-2013, project number POSDRU/159/1.5/S/142115, project title "Performance and Excellence in Postdoctoral Research in Romanian Economics Science Domain".

\section{References}

Aaker, D.A. (1991), Managing Brand Equity: Capitalizing on the Value of a Brand Name, The Free Press, New York.

Anselmsson, J., Vestman, N.B. and Johansson, U. (2014), "Brand image and customers' willingness to pay a price premium for food brands", Journal of Product \& Brand Management, Vol. 23, No. 2, pp. 90-102.

Carroll, A.B. (1979), "A Three-Dimensional Conceptual Model of Corporate Performance", Academy of Management Review, Vol. 4, No. 4, pp. 497-505. 
MMCKS Cronin Jr, J.J., Brady, M.K. and Hult, G.T.M. (2000), "Assessing the effects of quality, value, and customer satisfaction on consumer behavioral intentions in service environments", Journal of Retailing, Vol. 76, No. 2, pp. 193-218.

130 Dahlsrud, A. (2008), "How corporate social responsibility is defined: an analysis of 37 definitions", Corporate Social Responsibility and Environmental Management, Vol. 15, No. 1, pp. 1-13.

$\mathrm{Du}, \mathrm{S}$. , Bhattacharya, C.B., and Sen, S. (2007), "Reaping relational rewards from corporate social responsibility: The role of competitive positioning", International Journal of Research in Marketing, Vol. 24, No. 3, pp. 224-241.

Freeman, R.E., Harrison, J.S., Wicks, A.C., Parmar, B.L. and De Colle, S. (2010), Stakeholder theory: the state of the art, Cambridge University Press, Cambridge.

Jacoby, J. and Chestnut, R.W. (1978), Brand Loyalty: Measurement and Management, John Wiley and Sons, New York.

Kim, S.Y. and Park, H. (2011), "Corporate social responsibility as an organizational attractiveness for prospective public relations practitioners", Journal of Business Ethics, Vol. 103, No. 4, pp. 639-653.

Lusk, J. and Norwood, F.B. (2012), "Speciesism, altruism and the economics of animal welfare", European Review of Agricultural Economic, Vol. 39, No. 2, pp. 189-212.

Maignan, I. (2001), "Consumers' perceptions of corporate social responsibilities: a crosscultural comparison", Journal of Business Ethics, Vol. 30, No. 1, pp. 57-72.

Malhotra, N.K., Ulgado, F.M., Agarwal, J., Shainesh, G. and Wu, L. (2005), "Dimensions of service quality in developed and developing economies: multi-country crosscultural comparisons", International Marketing Review, Vol. 22, No. 3, pp. 256278.

Maloni, M. J. and Brown, M.E. (2006), "Corporate social responsibility in the supply chain: an application in the food industry", Journal of Business Ethics, Vol. 68, No. 1, pp. 35-52.

Martínez, P. and del Bosque, R.I. (2013), "CSR and customer loyalty: The roles of trust, customer identification with the company and satisfaction", International Journal of Hospitality Management, Vol. 35, No. 1, pp. 89-99.

McMullan, R. (2005), "A multiple-item scale for measuring customer loyalty development", Journal of Services Marketing, Vol. 19, No. 7, pp. 470-481.

Murdoch, J., Marsden, T. and Banks, J. (2000), "Quality, nature, and embeddedness: some theoretical considerations in the context of the food sector", Economic Geography, Vol. 76, No. 2, pp. 107-125.

Norris, M. and Oppenheim, C. (2007), "Comparing alternatives to the Web of Science for coverage of the social sciences' literature", Journal of Informetrics, Vol. 1, No. 2, pp. 161-169.

Öberseder, M., Schlegelmilch, B.B., Murphy, P.E. and Gruber, V. (2014), "Consumers' perceptions of corporate social responsibility: scale development and validation", Journal of Business Ethics, Vol. 124, No. 1, pp. 101-115.

Peloza, J. and Shang, J. (2011), "How can corporate social responsibility activities create value for stakeholders? A systematic review", Journal of the Academy of Marketing Science, Vol. 39, No. 1, pp. 117-135.

Pérez, A. and del Bosque, I. R. (2013), "Measuring CSR image: three studies to develop and to validate a reliable measurement tool", Journal of Business Ethics, Vol. 118, No. 2, pp. 265-286.

Perrini, F., Castaldo, S., Misani, N. and Tencati, A. (2010), “The impact of corporate social responsibility associations on trust in organic products marketed by mainstream 
retailers: a study of Italian consumers", Business Strategy and the Environment, MMCKS Vol. 19, No. 8, pp. 512-526.

Pirsch, J., Gupta, S., and Grau, S.L. (2007), "A framework for understanding corporate social responsibility programs as a continuum: An exploratory study", Journal of Business Ethics, Vol. 70, No. 2, pp. 125-140.

Pivato, S., Misani, N. and Tencati, A. (2008), "The impact of corporate social responsibility on consumer trust: the case of organic food", Business Ethics: A European Review, Vol. 17, No. 1, pp. 3-12.

Popa, M. and Salanță, I. (2014), "Corporate social responsibility versus corporate social iresponsibility", Management \& Marketing. Challenges for the Knowledge Society, Vol. 9, No. 2, pp. 137-146.

Reichheld, F. (2003), "The one number you need to grow", Harvard Business Review, Vol. 82, No. 6, pp. 46-54.

Rosenbaum, M. S. (2006), "Exploring the social supportive role of third places in consumers' lives". Journal of Service Research, Vol. 9, No. 1, pp. 59-72.

Salegna, G.J. and Goodwin, S.A. (2005), "Consumer loyalty to service providers. An integrated conceptual model". Journal of Consumer Satisfaction, Dissatisfaction and Complaining Behavior, Vol. 18, No. 1, pp. 51-67.

Salmones de los, M.G., Crespo, A.H. and del Bosque, I. R. (2005), "Influence of corporate social responsibility on loyalty and valuation of services". Journal of Business Ethics, Vol. 61, No. 4, pp. 369-385.

Sen, S. and Bhattacharya, C.B. (2001), "Does doing good always lead to doing better? Consumer reactions to corporate social responsibility". Journal of Marketing Research, Vol. 38, No. 2, pp. 225-243.

Singh, J.J., Iglesias, O. and Batista-Foguet, J.M. (2012), "Does having an ethical brand matter? The influence of consumer perceived ethicality on trust, affect and loyalty", Journal of Business Ethics, Vol. 111, No. 4, pp. 541-549.

Sloot, L.M., Verhoef, P.C. and Franses, P.H. (2005), "The impact of brand equity and the hedonic level of products on consumer stock-out reactions", Journal of Retailing, Vol. 81, No. 1, pp. 15-34.

Turker, D. (2009), "Measuring corporate social responsibility: A scale development study", Journal of Business Ethics, Vol. 85, No. 4, pp. 411-427.

Wagner, T., Bicen, P. and Hall, Z.R. (2008), "The dark side of retailing: towards a scale of corporate social irresponsibility", International Journal of Retail and Distribution Management, Vol. 36, No. 2, pp. 124-142.

Zeithaml, V. A., Berry, L.L. and Parasuraman, A. (1996), "The behavioral consequences of service quality", Journal of Marketing, Vol. 60, No. 1, pp. 31-46. 